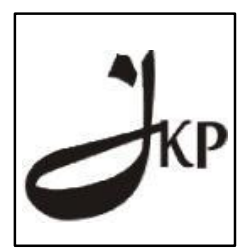

Jurnal Konseling dan Pendidikan

ISSN Cetak: 2337-6740 - ISSN Online: 2337-6880

http://jurnal.konselingindonesia.com

Volume 3 Nomor 2, Juni 2015, HIm 55-61

Info Artikel:

Diterima 14/04/2015

Direvisi 23/05/2015

Dipublikasikan 30/06/2015

\title{
Konsep Body Image Remaja Putri
}

Amandha Unziila Denich ${ }^{1} \&$ Ifdil $^{2}$

${ }^{1}$ Universitas Negeri Padang

${ }^{2}$ Universitas Negeri Padang

\begin{abstract}
Abstrak
Munculnya penilaian dikalangan remaja putri standar tubuh saat ini yang mementingkan penampilan fisik dengan bentuk tubuh yang proposional, telah membuat remaja putri saat ini menjadi kurang percaya diri, remaja putri selalu menilai dirinya melalui kaca mata oranglain yaitu teman-teman sepergaulannya. Berawal dari penampilan fisik, remaja mulai memberikan gambaran dan persepsi tentang bentuk fisik yang dimiliki, kemudian beranjak pada penampilan fisik yang dimiliki orang lain hingga standar tubuh yang harus dimiliki setiap perempuan. Gambaran dan persepsi tentang penampilan fisik inilah yang disebut body image.
\end{abstract}

Kata Kunci: Body Image, Remaja Putri

\begin{tabular}{l} 
Copyright (C) 2015 IICE - Multikarya Kons (Padang - Indonesia) da n I K I - Ikatan Konselor Indonesia All \\
Rights Reserved \\
Indonesian Institute for Counseling and Education (IICE) Multikarya Kons \\
\hline
\end{tabular}

PENDAHULUAN

Masa remaja dimulai sekitar usia 10 hingga 13 tahun dan berakhir pada sekitar usia 18 hingga 22 tahun (Santrock, 2007:20). Individu yang tergolong remaja akhir cenderung berada dalam keadaan labil dan emosional karena mengalami banyak perubahan-perubahan yang berlangsung cepat. Steinberg (dalam Indri, 2008:3) mengemukakan remaja pada usia 15-18 tahun mengalami banyak perubahan secara kognitif, emosional, dan sosial, berpikir lebih kompleks, secara emosional lebih sensitif, serta sering menghabiskan waktu bersama dengan teman-temannya. Hal ini relevan dengan pendapat Santrock (2007:20) yang menyatakan pada masa remaja terjadi proses peralihan perkembangan yang melibatkan perubahan-perubahan dalam diri individu, seperti perubahan biologis atau fisik, sosio-emosional, dan kognitif.

Perubahan fisik menimbulkan dampak psikologis yang tidak diinginkan. Mayoritas anak muda lebih banyak memperhatikan penampilan mereka ketimbang aspek lain dalam diri mereka, dan banyak di antara mereka yang tidak suka melihat apa yang mereka lihat di cermin. Anak perempuan memiliki perasaan tidak suka yang lebih tinggi dibandingkan anak laki-laki, mencerminkan penekanan kultural yang lebih besar terhadap atribut fisik wanita (Papalia, 2011:539). Pada usia rentangan usia 16-20 tahun, seorang wanita mulai menemukan nilai-nilai hidup baru, sehingga semakin jelaslah pemahaman tentang keadaan diri sendiri (Frischa. MY., Zadrian. A., \& Ifdil. 2013).

\footnotetext{
* Telp atau Alamat Email Koresponden :

* 1 Tel.: +6281366326494. E-mail address : ifdil@konselor.org
} 


\section{Jurnal Konseling dan Pendidikan}

Munculnya penilaian dikalangan remaja putri standar tubuh saat ini yang mementingkan penampilan fisik dengan bentuk tubuh yang proposional, telah membuat remaja putri saat ini menjadi kurang percaya diri, remaja putri selalu menilai dirinya melalui kaca mata oranglain yaitu teman-teman sepergaulannya (Ratnawati, 2012:1). Berawal dari penampilan fisik, remaja mulai memberikan gambaran dan persepsi tentang bentuk fisik yang dimiliki, kemudian beranjak pada penampilan fisik yang dimiliki orang lain hingga standar tubuh yang harus dimiliki setiap perempuan. Gambaran dan persepsi tentang penampilan fisik inilah yang disebut body image.

\section{BODY IMAGE}

Pengertian body image menurut Arthur (2010) adalah imajinasi subyektif yang dimiliki seseorang tentang tubuhnya, khususnya yang terkait dengan penilaian orang lain, dan seberapa baik tubuhnya harus disesuaikan dengan persepsi-persepsi ini. Beberapa peneliti atau pemikir menggunakan istilah ini hanya terkait tampilan fisik, sementara yang lain mencakup pula penilaian tentang fungsi tubuh, gerakan tubuh, koordinasi tubuh, dan sebagainya. Burn (1993:189) body iamge merupakan gambaran yang dimiliki seseorang mengenai dirinya sendiri sebagai makhluk yang mempunyai fisik, fisik yang dimaksud disini adalah bentuk tubuh seorang remaja, karena pada masa remaja, seorang akan mengalami pubertas, dimana kita ketahui ketika seorang remaja harus siap menerima perubahan pada dirnya.

Setiap individu memiliki gambaran diri ideal seperti apa yang diinginkannya termasuk bentuk tubuh ideal seperti apa yang dimilikinya. Ketidaksesuaian antara bentuk tubuh yang dipersepsi oleh individu dengan bentuk tubuh yang menurutnya ideal akan memunculkan ketidakpuasan terhadap tubuhnya (Amalia, 2007). Citra tubuh mulai terbentuk jauh sebelum seorang anak mampu mengungkapkan fikiran-fikiran maupun ide-idenya lewat kata-kata. Melalui kemampuan fisiknya seorang anak mempersepsi dirinya sebagai seseorang yang dapat menyebabkan sesuatu terjadi, misalnya dengan menggunakan tangannya sebagai alat (Amalia, 2007).

Tingkat Body image individu digambarkan oleh seberapa jauh individu merasa puas terhadap bagian-bagian tubuh dan penampilan fisik secara keseluruhan serta menambahkan tingkat penerimaan citra raga sebagian besar tergantung pada pengaruh sosial budaya yang terdiri dari empat aspek yaitu reaksi orang lain, perbandingan dengan orang lain, peranan individu dan identifikasi terhadap orang lain (Thompson, 2000). Pengertian Body Image menurut Honigam dan Castle (Januar, 2007) adalah gambaran mental seseorang terhadap bentuk dan ukuran tubuhnya, bagaimana seseorang mempersepsi dan memberikan penilaian atas apa yang dipikirkan dan rasakan terhadap ukuran dan bentuk tubuhnya, dan atas penilaian orang lain terhadap dirinya. Sebenarnya, apa yang dipikirkan dan rasakan olehnya, belum tentu benar-benar mempresentasikan keadaan yang aktual, namun lebih merupakan hasil penilaian diri yang bersifat subjektif.

Body image menurut Hoyt (Naimah, 2008) diartikan sebagai sikap seseorang terhadap tubuhnya dari segi ukuran, bentuk maupun estetika berdasarkan evaluasi individual dan pengalaman efektif terhadap atribut fisiknya. Body image bukan sesuatu yang statis, tetapi selalu berubah. Pembentukannya dipengaruhi oleh persepsi, imajinasi, emosi, suasana hati, lingkungan, dan pengalaman fisik. Dengan demikian, proses komparasi sosial pasti terjadi dalam membentuk body image remaja. Menurut Hardisuryabrata (1997:11) body image bersifat subyektif, sebab hanya didasarkan pada interprestasi pribadi tanpa mempertimbangkan atau meneliti lebih jauh dari kenyataan yang sebenarnya.

Dari uraian di atas, dapat disimpulkan body image merupakan gambaran persepsi seseorang tentang tubuh ideal dan apa yang mereka inginkan pada tubuh mereka baik itu dalam hal berat maupun bentuk tubuh yang didasarkan pada persepsi-persepi orang lain dan seberapa harus mereka menyesuaikan persepsi tersebut. Seseorang menganggap kondisi fisiknya tidak sama dengan konsep idealnya, maka individu tersebut akan merasa memilki kekurangan secara fisik meskipun dalam pandangan orang lain sudah dianggap menarik. Keadaan seperti itu yangsering membuat seseorang tidak dapat menerima kondisi fisiknya secara apa adanya sehingga body imagenya menjadi negatif. Jika seorang wanita merasa gemuk dan memiliki berat badan yang berlebih, mereka cenderung merasa tidak puas dengan kondisi tubuhnya dan menginginkan berat tubuhnya berkurang. Kesenjangan yang terlalu jauh antara tubuh yang dipersepsi dengan gambaran idealnya akan menyebabkan penilaian yang negatif terhadap tubuhnya, hal tersebut yang membuat mereka memiliki kepercayaan diri yang rendah akibat dari penilaian yang negatif terhadap body image yang tidak sesuai dengan gambaran idealnya. 


\section{FAKTOR YANG MEMPENGARUHI BODY IMAGE}

Body image terbentuk dari sejak individu lahir sampai selama individu hidup. Banyak hal yang dapat mempengaruhi body image seseorang termasuk pandangan atau penilaian orang lain terhadap penampilan diri sendiri. Beberapa ahli menyatakan ada berbagi faktor yang dapat mempengaruhi body image seseorang adapun faktor-faktor yang mempengaruhi perkembangan body image menurut Cash (1994) adalah sebagai berikut :

1. Jenis kelamin

Jenis kelamin merupakan faktor yang mempengaruhi dalam perkembangan body image seseorang (Phares, V., Steinberg, A. R., \& Thompson, J. K. 2004; Cash, T. F., Melnyk, S. E., \& Hrabosky, J. I. 2004; ). Cash (1994) menyatakan ketidakpuasan terhadap tubuh lebih sering terjadi pada wanita daripada laki-laki. Pada umumnya wanita, lebih kurang puas dengan tubuhnya dan memiliki body image yang negatif. Wanita biasanya lebih kritis terhadap tubuh mereka baik secara keseluruhan maupun pada bagian tertentu tubuh mereka daripada laki-laki. Persepsi body image yang buruk sering berhubungan dengan perasaan kelebihan beratbadan terutama pada wanita. Seorang laki-laki ,lebih memperhatikan masa otot ketika mempertimbangkan body image mereka.

Umumnya body image yang buruk dapat menyebakan diet konstan dan diet yang bersifat sementara, obesity, dan gangguan makan serta dapat menyebabkan rendahnya harga diri, depresi, kecemasan dan keseluruhan tekanan emosional. Sebuah penelitian (Cash,1994) menjelaskan sekitar 40-70\% gadis remaja tidak puas dengan dua atau lebih aspek dari tubuh mereka. Ketidakpuasan biasanya berfokus pada jaringan adipose substansial dalam tubuh bagian tengah atau bawah, seperti pinggul, perut dan paha. Di berbagai Negara maju , antara 50-80 \% gadis remaja ingin menjadi langsing dan melakukan diet bervariasi dari $20 \%$ hingga 60\% (Mansfield, L. 2011; Mansfield, L. 2011). Seorang laki-laki juga ingin menghindari bentuk tubuh gemuk, lembek, namun dikalangan lelaki yang tidak puas dengan berat dan bentuk berusaha untuk menambah berat badan untuk mengembangkan lengan atas, dada dan bahu.

2. Media massa

Media massa yang muncul dimana-mana memberikan gambaran ideal mengenai figure perempuan dan lakilaki yang dapat mempengaruhi gambaran tubuh seseorang. Tiggeman (Cash, 1994) menyatakan media massa menjadi pengaruh kuat dalam budaya social. Anak-anak dan remaja lebih banyak menghabiskan waktunya dengan menonton televisi dan kebanyakan orang dewasa membaca surat kabar harian dan majalah. Survey media massa menunjukkan $83 \%$ majalah fashion khususnya dibaca oleh mayoritas permpuan maupun anak perempuan.

Konsumsi media yang tinggidapat mempengaruhi konsumen dalam berbagai cara. Isi tayangan media massa sering menggambarkan standart kecantikan perempuan adalah tubuh yang kurus, dalam hal ini berarti level kekurusan yang dimilki, kebanyakan wanita percaya mereka adalah orang-orang yang sehat. Media juga menggambarkan gambaran ideal bagi laki-laki adalah dengan memilki tubuh yang berotot dan perut yang rata. Menurut Longe (dalam Cash, 1994) body image dapat dipengaruhi oleh pengaruh luar. Sumber media, seperti televise, internet, dan majalah sering menggambarkan orang lebih dekat dengan tipe tubuh yang ideal umum diterima daripada citra tubuh rata-rata, untuk menjual produk mereka. Akibatnya, orang-orang, terutama anak-anak dan dewasa muda yang terlalu dipengaruhi dan terpengaruh oleh penggambaran seperti citra tubuh tersebut. Levine dan Smolak (dalam Cash, 1994) menyimpulkan dengan melihat foto-foto model yang langsing membuat gadis dan perempuan merasa buruk tentang tubuh mereka, beberapa penelitian menunjukkan dampak negatif. Secara singkat media menciptakan citra seorang wanita itu langsing pada majalah fashion terbukti menyebabkan sejumlah efek negative secara langsung termasuk perhatian yang lebih besar tentang berat badan, ketidakpuasan tubuh, suasana hati yang negatif ,dan penurunan persepsi daya tarik diri.

3. Hubungan Interpersonal

Hubungan interpersonal membuat seseorang cenderung membandingkan diridengan orang lain dan feedback yang diterima mempengaruhi konsep diri termasuk mempengaruhi bagaimana perasaan terhadap penampilan fisik. Hal inilah yang sering membuat orang merasa cemas dengan penampilannya dan gugup ketika orang lain melakukan evaluasi terhadap dirinya. Rossen dan koleganya (Cash, 1994) menyatakan feedback terhadap penampilan dan kompetensi teman sebaya dan keluarga dalam hubungan interpersonal dapat mempengaruhi bagaimana pandangan dan perasaan mengenai tubuh. 
Dunn dan Gooke (Cash, 1994) menerima feedback mengenai penampilan fisik mereka berarti seseorang mengembangkan persepsi tentang bagaimana seseorang melakukan perbandingan social yang merupakan salah satu proses pembentukan dalam penilaian diri mengenai daya tarik fisik. Pikiran dan perasaan mengenai tubuh bermula dari adanya reaksi orang lain. Dalam konteks perkembangan, body image berasal dari hubungan interpersonal. Perkembangan emosional dan pikiran individu juga berkontribusi pada bagaimana seseorang melihat dirinya. Maka, bagaimana seseorang berpikir dan merasa mengenai tubuhnya dapat mempengaruhi hubungan dan karakteristik psikologis.

Banyak hal yang dapat mempengaruhi body image. Sejalan dengan itu, Thompson (2000) mengemukakan faktor-faktor yang mempengaruhi body image adalah

1. Pengaruh berat badan dan persepsi gemuk/kurus

Keinginan-keinginan untuk menjadikan berat badan tetap optimal dengan menjaga pola makan yang teratur, sehinnga persepsi terhadap citra tubuh yang baik akan sesuai dengan diinginanya.

2. Budaya

Adanya pengaruh disekitar lingkungan individu dan bagaimana cara budaya mengkomunikasikan normanorma tentang penampilan fisik, dan ukuran tubuh yang menarik.

3. Siklus hidup

Pada dasar Individu menginginkan untuk kembali memiliki bentuk tubuh seperti masalalu.

4. Masa kehamilan

Proses dimana individu bisa menjaga masa tumbuh kembang anak dalam kandungan, tanpa ada peristiwa-peristiwa pada masa kehamilan.

5. Sosialisasi

Adanya pengaruh dari teman sebaya yang menjadikan individu ikut terpengaruh didalamnya.

6. Konsep diri

Gambaran Individu terhadap dirinya, yang meliputi penilaian diri dan penilaian sosial.

7. Peran gender

Dalam hal ini peran orang tua sangat penting bagi citra tubuh individu, sehingga menjadikan individu lebih cepat terpengaruh

8. Pengaruh distorsi citra tubuh pada diri individu

Perasaan dan persepsi individu yang bersifat negatif terhadap tubuhnya yang dapat diikuti oleh sikap yang buruk.

Di antara komponen tersebut, yang memiliki pengaruh lebih besar adalah budaya yaitu keindahan tubuh dan standar tentang tubuh ditentukan oleh masyarakat. Dengan kata lain, masyarakat menilai apa yang dikatakan indah, ideal, danapa yang tidak. Kecantikan wanita yang ideal telah bervariasi dan berubah sesuai standar estetika jangka waktu tertentu dan sebagian besar wanita telah berusaha untuk mengubah diri mereka sendiri untuk memenuhi citra ideal ini (Thomson, 2000).

Adanya trend mengenai citra ideal dapat mempengaruhi persepsi individu terhadap tubuhnya, hal tersebut akan membuat individu cenderung membandingkan antara persepsi tubuh dan penampilannya sendiri dengan penampilan ideal yang mereka bayangkan, apabila terdapat kesenjangan yang terlalu jauh antara tubuh nyatanya dengan tubuh idealnya, individu akan merasakecewa, frustasi, sedih atau merasa ada satu kebutuhan yang tidak terpenuhi. Penelitian lain menekankan kecenderungan untuk membandingkan penampilan fisik sendiri pada orang lain secara kuat terkait dengan ketidakpuasan tubuh (Thompson, 2000).

Pada studi lain, terdapat indikasi mayoritas variasi dari body image dan gangguan pola makan bisa dikaitkan dengan kecenderungan untuk menyadari dan menginternalisasikan norma sosiokultural mengenai penampilan yang menarik (Thompson, 2000). Media massa menjadi faktor yang penting dalam membentuk nilai-nilai yang dianut di masyarakat (Wei, R., \& Pan, Z. 1999). Melalui media massa, tubuh yang ideal terbentuk di masyarakat. Di Indonesia sendiri dapat dilihat peran media massa mulai mempunyai pengaruh dalam membentuk pikiran tentang penampilan dan body image, pada iklan-iklan kosmetik sering digunakan model wanita dengan kulit yang putih, tubuh yang langsing, secara tidak sadar masyrakat menganggap tubuh ideal seorang wanita adalah yang memiliki kulit putih dan bertubuh langsing. 


\section{ASPEK-ASPEK BODY IMAGE}

Body image terbagi dalam beberapa aspek. Menurut Cash dan Puzinsky (dalam Seawell, A. H \& Danorf Burg, 2005) mengenai body image pada umumnya menggunakan Multidemensional Body Self Relation Questionnaire-Appearance Scale (MBSRQ-AS), yaitu:

1. Appearance evaluation (evaluasi penampilan)

Evaluasi penampilan yaitu mengukur penampilan keseluruhan tubuh, apakah menarik atau tidak menarik serta memuaskan atau belum memuaskan.

2. Appearance orientation (orientasi penampilan)

Orientasi penampilan yaitu perhatian individu terhadap penampilan dirinya dan usaha yang dilakukan untuk memperbaiki dan meningkatkan penampilan diri.

3. Body area satisfaction (kepuasan terhadap bagian tubuh)

Kepuasan terhadap bagian tubuh, yaitu mengukur kepuasan individu terhadap bagian tubuh secara spesifik, wajah, tubuh bagian atas (dada, bahu lengan), tubuh bagian tengah (pinggang, perut), tubuh bagian bawah (pinggul, paha, pantat, kaki), serta bagian tubuh secara keseluruhan.

4. Overweight preoccupation (kecemasan menjadi gemuk)

Kecemasan menjadi gemuk yaitu mengukur kewaspadaan individu terhadap berat badan, kecenderungan untuk melakukan diet, dan membatasi pola makan

5. Self-classified weight (Pengkategorian ukuran tubuh)

Pengkategorian ukuran tubuh, yaitu mengukur bagaimana individu menilai berat badannya, dari sangat kurus sampai gemuk.

Menurut Thompson (2000) tingkat citra raga individu digambarkan oleh seberapa jauh individu merasa puas terhadap bagian-bagian tubuh dan penampilan fisik secara keseluruhan serta menambahkan tingkat penerimaan citra raga sebagian besar tergantung pada pengaruhsosial budaya yang terdiri dari empat aspek yaitu reaksi orang lain, perbandingan dengan oranglain, peranan individu dan identifikasi terhadap orang lain. Komponen citra raga terdiri dari komponen perseptual dan komponen sikap menjadi landasan pengukuran.

Komponen perseptual menunjukkan bagaimana individu menggambarkan kondisi fisiknya. Oleh karena itu penilaian merupakan aspek yang tepat untuk mewakili komponen-komponen tersebut. Komponen sikap mengarah pada perasaaan dan sikap yang muncul darikondisi tersebut. Perasaan diwakili dengan tingkat kepuasan dan ketidakpuasan individu terhadaptubuhnya, sedangkan sikap diwakili oleh harapan-harapan mengenai tubuhnya, sebagai akibatdari harapan biasanya menjadi tindakan demi mewujudkan harapan tersebut (Thompson, 2000).

Oleh karena itu aspek perasaan dan aspek harapan mewakili seluruh komponen sikap.Thompson (2000) menjelaskan aspek-aspek dalam citra raga yaitu:

1. Persepsi terhadap bagian-bagian tubuh dan penampilan secara keseluruhan.

Bentuk tubuh merupakan suatu simbol dari diri seorang individu, karna dalam hal tersebut individu dinilai oleh orang lain dan dinilai oleh dirinya sendiri. Selanjutnya bentuk tubuh serta penampilan baik dan buruk dapat mendatangkan perasaan senang atau tidak senang terhadap bentuk tubuhnya sendiri.

2. Aspek perbandingan dengan orang lain

Adanya penilaian sesuatu yang lebih baik atau lebih buruk dari yang lain, sehingga menimbulkan suatu prasangka bagi dirinya keorang lain, hal-hal yang menjadi perbandingan individu ialah ketika harus menilai penampilan dirinya dengan penampilan fisik orang lain.

3. Aspek sosial budaya (reaksi terhadap orang lain).

Seseorang dapat menilai reaksi terhadap orang lain apabila dinilai orang itu menarik secara fisik, maka gambaran orang itu akan menuju hal-hal yang baik untuk menilai dirinya. 
KESIMPULAN

Pada masa remaja terjadi berbagai perubahan baik perubahan hormonal, fisik, psikologis maupun sosial. Perubahan fisik menimbulkan dampak psikologis yang tidak diinginkan. Mayoritas anak muda lebih banyak memperhatikan penampilan mereka ketimbang aspek lain dalam diri mereka, dan banyak di antara mereka yang tidak suka melihat apa yang mereka lihat di cermin. Anak perempuan memiliki perasaan tidak suka yang lebih tinggi dibandingkan anak laki-laki, mencerminkan penekanan kultural yang lebih besar terhadap atribut fisik wanita.

Munculnya penilaian dikalangan remaja putri standar tubuh saat ini yang mementingkan penampilan fisik dengan bentuk tubuh yang proposional, telah membuat remaja putri saat ini menjadi kurang percaya diri, remaja putri selalu menilai dirinya melalui kaca mata oranglain yaitu teman-teman sepergaulannya. Berawal dari penampilan fisik, remaja mulai memberikan gambaran dan persepsi tentang bentuk fisik yang dimiliki, kemudian beranjak pada penampilan fisik yang dimiliki orang lain hingga standar tubuh yang harus dimiliki setiap perempuan. Gambaran dan persepsi tentang penampilan fisik inilah yang disebut body image.

Body image yang dimiliki remaja banyak mengarah pada hal negatif, seperti diet yang berlebihan untuk mencapai postur badan ideal. Ini akan memperngaruhi bagaimana remaja menjalani kehidupan normal dengan tekanan memiliki tubuh yang ideal. Dengan demikian, remaja yang sedang mengalami perubahan dan cendrung meniru orang lain yang baginya ideal perlu mendapatkan bimbingan dan pengarahan agar cara yang dijalani tidak salah dan merusak dirinya sendiri.

\section{DAFTAR PUSTAKA}

Ali, Mohammad dan Asrosi. (2012). Psikologi Remaja. Jakarta: Bumi Aksara.

Amalia, L. (2007). Citra Tubuh (Body Image) Remaja Perempuan. Jurnal Musawa, 5(4).STAIN Ponorogo.

Arthur, S. R. \& Emily S. R. (2010). Kamus Psikologi. Yogyakarta: Pustaka Pelajar.

Burns, R.B. (1993). Konsep Diri: Teori Pengukuran, Perkembangan, Perilaku. Terjemahan oleh Teddy.

Cash, T. F. (1994). Body Image Attitudes : Evaluation, Investment and Affect : Perceptual Motor Skills. Journal of psychology, (78), 1168-1170.

Cash, T. F., Melnyk, S. E., \& Hrabosky, J. I. (2004). The assessment of body image investment: An extensive revision of the Appearance Schemas Inventory. International Journal of Eating Disorders, 35(3), 305-316.

Yendi, F. M., Ardi, Z., \& Ifdil, I. (2013). Pelayanan Konseling untuk Remaja Putri Usia Pernikahan. Jurnal Konseling dan Pendidikan, 1(2), 109-114.

Hardisuryabrata, MS. (1997). Mengembangkan Citra Diri yang Positif. Jakarta: Obor offset.

Indri, K, N. (2008). "Stres Pada Remaja" . Skripsi . Medan: Psikologi Universitas Sumatera Utara. Jakarta: Arcan.

Januar, V. (2007). Citra Tubuh Pada Remaja Putri Menikah dan Memiliki Anak. Jurnal Psikologi. 3(3). Jakarta: Fakultas Psikologi Universitas Gunadarma.

Mansfield, L. (2011). 4 Fit, Fat and Feminine?. Women and Exercise: The Body, Health and Consumerism, 5, 81.

Na'imah, T. (2008). Pengaruh Komparasi Sosial pada Public Figure di Media Massa Terhadap Body Image Remaja di Kecamatan Patikraja, Kabupaten Banyumas, Jurnal Psikologi Penelitian Humaniora. 9(2). Universitas Muhammadiyah Purwokerto. 
Nazir, M. (2011). Metode Penelitian. Bogor: Ghalia Indonesia.

Papalia, Diane E., et al. (2011). Human Development (Psikologi Perkembangan). Jakarta: Kencana.

Phares, V., Steinberg, A. R., \& Thompson, J. K. (2004). Gender differences in peer and parental influences: Body image disturbance, self-worth, and psychological functioning in preadolescent children. Journal of Youth and Adolescence, 33(5), 421-429.

Ratnawati, V. (2012). Percaya Diri, Body Image dan Kecendrungan Anorexia Nervosa pada Remaja Putri. Jurnal Psikologi Indonesia 1(2). Kediri: Universitas PGRI Indonesia.

Santrock, Jhon, W. (2003). Adolescene: Perkembangan Remaja. Terjemahan oleh Shinto B. Adelar dan Sherly Siragih. Jakarta: Erlangga.

Santrock, Jhon, W. (2007). Remaja jilid 2. Terjemahan oleh Sherly Saragih. Jakarta: Erlangga.

Seawell, A, H \& Danorf-Burg, S. (2005). Body Image and Sexuality In Woman With And Without Systemic Lupus Erythematosus. Sex Roles, 5(11/12), 865-876.

Thompson, J. K. (2000). Body Image, Eating Disorders, and Obesity. Amarican Psychological Association. Washington, DC.

Wei, R., \& Pan, Z. (1999). Mass media and consumerist values in the People's Republic of China. International Journal of Public Opinion Research, 11(1), 75-96. 